\title{
Phacoemulsification of bilateral cataracts in a loggerhead sea turtle (Caretta caretta)
}

\author{
T. R. Kelly, W. Walton, B. Nadelstein, G. A. Lewbart
}

\begin{abstract}
An immature free-living loggerhead sea turtle (Caretta caretta) of unknown sex was found moribund off the coast of Wise Point, Virginia. It was suffering from cachexia and had bilateral hypermature cataracts which were treated by phacoemulsification under general anaesthesia. The surgery restored the turtle's vision and it was returned to the wild.
\end{abstract}

THE loggerhead sea turtle (Caretta caretta) is a threatened species that has a fragmented range in areas of the south-eastern USA, eastern Australia, southern Brazil, the Mediterranean Sea, and areas of the Indian Ocean (Pritchard 1997). Sea turtle populations are declining owing to loss of habitat as a result of development (Groombridge 1990, Allen 1992, Eckert and Honebrink 1992, Meylan and others 1995, Witherington and Martin 1996), boat strike (Virginia Institute of Marine Science 2005), pollution (Balazs 1985, Witzell and Teas 1994, Lutcavage and others 1995), infectious diseases (Wolke and others 1982, Gordon and others 1993, 1998, Brooks and others 1994, Williams and others 1994, Lackovich and others 1999) and incidental capture by devices used by commercial fisheries, such as shrimp trawls (National Research Council 1990, Reichart and Fretey 1993, Limpus and Reimer 1994), longlines (Nishemura and Nakahigashi 1990, Balazs and others 1995), and driftnets (Wetherall and others 1993).

Cataracts in reptiles may be genetically predisposed, or due to nutritional imbalances, trauma or uveitis (Millichamp and others 1983). This paper describes the treatment of bilateral cataracts in a loggerhead sea turtle by phacoemulsification. After the surgery, the turtle was able to navigate and find food within its enclosure, and was later released to the wild.

\section{CASE REPORT}

An immature loggerhead sea turtle of unknown sex was evaluated for bilateral cataracts that were discovered after it had been rescued by staff from the Eastern Shore of Virginia National Wildlife Refuge. It was found floating approximately $150 \mathrm{~m}$ off the shore of Wise Point, Virginia on April 30, 2002. On examination, the turtle was depressed, but responsive to stimuli. It was cachectic, weighed $43.2 \mathrm{~kg}$, and the curved length and width of its carapace were $72 \mathrm{~cm}$ and $69.5 \mathrm{~cm}$, respectively. There were two healed fractures over the dorsal caudal aspect of the carapace that were approximately $23 \mathrm{~cm}$ and $13 \mathrm{~cm}$ long. The turtle's shell was covered by a heavy burden of epibiota; the cataracts were hypermature (Fig 1).

The turtle's packed-cell volume was 26 per cent, within the normal range of 24 to 34 per cent (Whitaker and Krum 1999), but the following biochemical abnormalities were recorded: low concentrations of glucose $(2.53 \mathrm{mmol} / \mathrm{l}$, normal range 4.51 to $6.49 \mathrm{mmol} / \mathrm{l})$, calcium $(1.53 \mathrm{mmol} / \mathrm{l}$, normal range 1.6 to $2 \cdot 25 \mathrm{mmol} / \mathrm{l})$ and blood urea nitrogen $(18.9 \mathrm{mmol} / \mathrm{l}$, normal range 28.2 to $37.5 \mathrm{mmol} / \mathrm{l}$ ), and a low activity of alkaline phosphatase ( $6 \mathrm{U} / \mathrm{l}$, normal range 28 to $78 \mathrm{U} / \mathrm{l})$, and hyperphosphataemia $(3 \cdot 19 \mathrm{mmol} / \mathrm{l}$, normal range 1.49 to $2 \cdot 33$ $\mathrm{mmol} / \mathrm{l}$ ) (George 1995). A complete blood count was not performed when the turtle was admitted.

The turtle was given a solution consisting of two parts $2 \cdot 5$ per cent dextrose $/ 0 \cdot 45$ per cent sodium chloride to one part lactated Ringer's solution, $300 \mathrm{ml}$ subcutaneously and $800 \mathrm{ml}$ intracoelomically, $0 \cdot 1 \mathrm{mg} / \mathrm{kg}$ dexamethasone sodium phosphate (Vetus Animal Health) intravenously, $2 \mathrm{mg} / \mathrm{kg}$ vitamin B complex (Phoenix Pharmaceutical) intramuscularly, and 10 $\mathrm{mg} / \mathrm{kg}$ ampicillin (Polyflex; Fort Dodge Laboratories) intramuscularly; the ampicillin was continued at the same dose once a day for three more days. This treatment regimen was standard protocol for stranded sea turtles at the Virginia Marine Science Museum and was performed under the supervision of a contract veterinarian. The turtle's eyes were flushed with saline ophthalmic solution, and neomycin-polymyxin B-dexamethasone ophthalmic ointment (Alcon Laboratories) was applied. The turtle was kept overnight in a padded box in a quiet, warm area, with rolled wet towels under the edges of its plastron; starting the following day it was fed herring and squid by using a pole to place the food close to its mouth.

A complete ophthalmological examination was made by slit lamp biomicroscopy; indirect ophthalmoscopy was not possible due to the bilateral hypermature cataracts. The cataract in the right eye was approximately 75 per cent complete and obscured the view of the fundus. A large, broad posterior synechia was present dorsally. The lens had undergone slight resorption and there was a small clear area ventrally. The anterior lens capsule had multiple small white plaques. The cataract in the left eye was 85 per cent complete, with no evidence of resorption. The pupillary light reflexes were decreased and the turtle's menace response was absent bilaterally. A positive optic dazzle response was present bilaterally. The intraocular pressures, measured by applanation tonometry (Tonopen; Mentor Ophthalmics), were $14 \mathrm{mmHg}$ in the right eye and $19 \mathrm{mmHg}$ in the left eye.

The ophthalmological examination was repeated one month and three months later and no changes were observed. Four months after the first examination a fourth examination was made because the turtle's vision appeared to have deteriorated markedly. The cataract in the right eye was now 95 per cent complete and denser, and it had undergone more resorption (Fig 1). The cataract in the left eye was 100 per cent complete and no fundic reflex was detectable.

Further biochemical analyses, on September 8, 2002, showed that the turtle had a slightly high concentration of blood urea nitrogen ( $42.13 \mathrm{mmol} / \mathrm{l}$, normal range 28.2 to $37.5 \mathrm{mmol} / \mathrm{l})$ and a high activity of aspartate aminotransferase (518 U/l, normal range 165 to $405 \mathrm{U} / \mathrm{l}$ ) (George 1995). A complete blood count showed that the turtle's haematological parameters were within their normal ranges (Whitaker and Krum 1999).

\section{Surgery}

For seven days preoperatively, the turtle received the following treatment with topical antibiotic and steroidal ophthalmic solutions and systemic antibiotics. Both eyes were flushed twice a day with saline ophthalmic solution, and one to two drops of prednisolone acetate ophthalmic suspension (Pacific Pharma) were placed in each eye twice daily. On the day before surgery, this medication was changed to neomycinpolymyxin B-dexamethasone ophthalmic ointment given twice. The purpose of including a topical antibiotic in the regimen was to attempt to reduce the numbers of conjunctival bacteria. Systemic antibiotic therapy was initiated with 5 $\mathrm{mg} / \mathrm{kg}$ ampicillin intramuscularly once a day and amikacin
Veterinary Record (2005) $156,774-777$

\section{T. R. Kelly, DVM,}

G. A. Lewbart, MS, VMD, DipACZM,

Environmental Medicine Consortium and Department of Clinical Sciences, College of Veterinary Medicine, North Carolina State University, 4700 Hillsborough Street, Raleigh, NC 27606, USA W. Walton, LVT,

Virginia Aquarium and Marine Science Center Stranding Program, 717 General Booth Boulevard, Virginia Beach, VA 23451, USA

B. Nadelstein, DVM, DipACVO,

Animal Eye Care, 1100 Eden Way North, Chesapeake, VA 23320, USA

Dr Kelly is also at Hanes Medical Center, North Carolina Zoological Park, Asheboro, NC 27205, USA 
FIG 1: Cataract in one eye of the loggerhead sea turtle

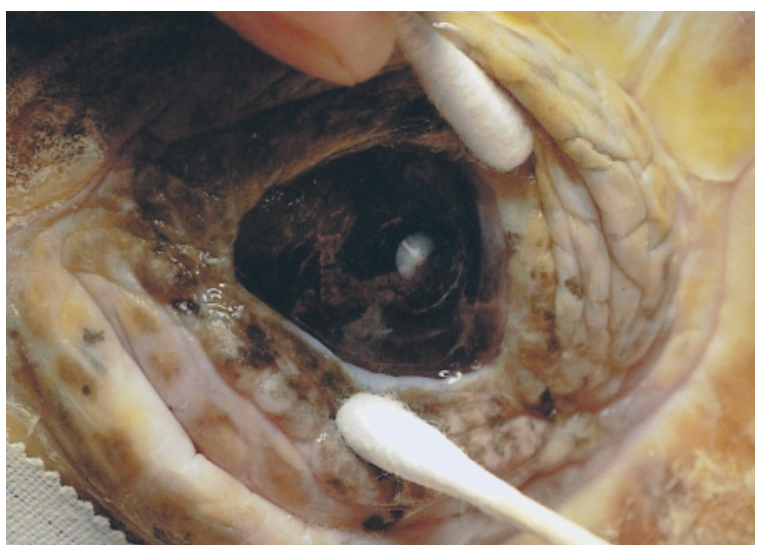

(Amiglyde V; Fort Dodge Laboratories) at a dose of $5 \mathrm{mg} / \mathrm{kg}$ initially and then $2.5 \mathrm{mg} / \mathrm{kg}$ intramuscularly every 72 hours.

On the day of the surgery, September 23, the turtle was given neomycin-polymyxin B-dexamethasone ophthalmic suspension (Alcon Laboratories) and a non-steroidal antiinflammatory ophthalmic solution, flurbiprofen sodium (Bausch \& Lomb), in both eyes four times, five to 10 minutes apart. Two doses of phenylephrine ophthalmic solution (Alcon Laboratories) were applied in each eye five minutes apart to constrict the conjunctival vasculature.

Anaesthesia was induced with $50 \mu \mathrm{g} / \mathrm{kg}$ medetomidine hydrochloride (Domitor; Pfizer Animal Health) and $5 \mathrm{mg} / \mathrm{kg}$ ketamine hydrochloride (Ketaset; Fort Dodge Animal Health) administered intravenously in the dorsal cervical sinus (Chittick and others 2002), and a 20-gauge polyurethane catheter was placed into the same sinus for the delivery of Plasmalyte-A (Baxter Healthcare Corporation) at 2.5 $\mathrm{ml} / \mathrm{kg} / \mathrm{hr}$ intraoperatively. Once the jaws were relaxed, a bite block $(15.3 \mathrm{~cm} \times 3.2 \mathrm{~cm}$ PVC T-piece) was inserted into the turtle's mouth to hold its jaws open and provide access to the glottis. Curved haemostats (artery forceps) were used gently to open the glottis for the placement of a $6.5 \mathrm{~mm}$ endotracheal tube, and anaesthesia was maintained with between 1.5 and 3 per cent sevoflurane (SevoFlo; Abbot Animal Health). The turtle was ventilated throughout the surgery up to the time of recovery with a pressure-controlled ventilator (ADS1000; Engler Engineering Corporation). Its heart rate and rhythm, end-tidal partial pressure of carbon dioxide, and cloacal temperature were monitored continuously (Chittick and others 2002). Flunixin meglumine at a dose of $0 \cdot 1 \mathrm{mg} / \mathrm{kg}$ (Banamine; Schering-Plough) was administered intramuscularly preoperatively to decrease inflammation.

A wire lid speculum was used to retract the eyelids and the periocular skin was prepared for surgery with topical 5 per cent povidone iodine solution. Three applications of topical proparacaine hydrochloride solution (Solvay Pharmaceuticals) were administered five minutes apart to provide local anaesthesia. A $2.8 \mathrm{~mm}$, three-quarters depth groove incision was made in the dorsotemporal cornea approximately $0.5 \mathrm{~mm}$ from the corneoscleral limbus. A keratome was then used to make a stab incision in the groove to enter the anterior chamber. Sodium hyaluronate (Hylartin-V; Upjohn) was introduced into the incision with a 27 -gauge cannula to maintain the shape of the anterior chamber. A solution of atracurium besylate (Ben Venue Laboratories) $(0.05 \mathrm{ml}$ of a $10 \mathrm{mg} / \mathrm{ml}$ solution of atracurium besylate diluted to $0.5 \mathrm{ml}$ with a balanced salt solution) was also injected into the anterior chamber in an attempt to dilate the pupil. A 25-gauge needle was used to start the anterior capsulotomy in a crescent shape in the centre of the lens, and a continuous curvilinear capsulorrhexis was completed by using utrata forceps. The cataracts were phacoemulsified by using an OMS/Allergen Diplomax unit with a $30^{\circ}$ tip at 30 to 70 per cent phacoemulsification

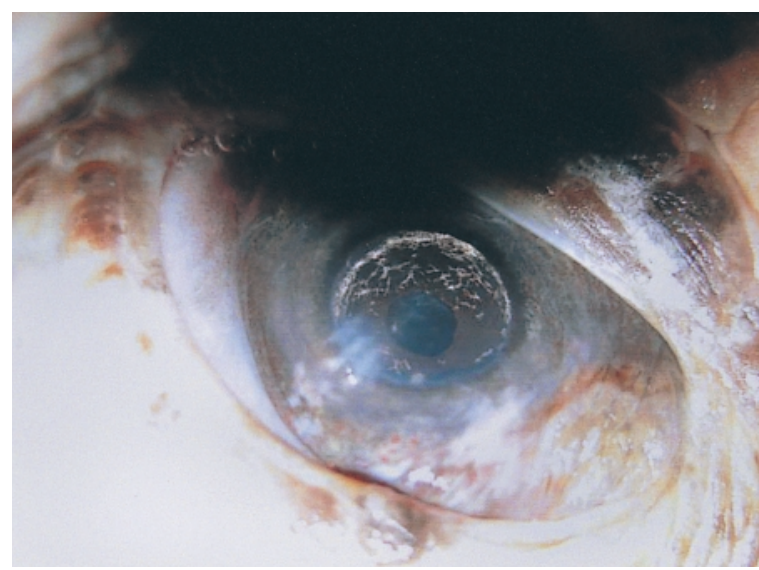

FIG 2: Appearance of the eye of the turtle after phacoemulsification

power. The corneal incisions were closed with 8-0 polygalactin 910 (Ethicon) with three simple interrupted sutures. Atipamezole (Antisedan: Pfizer Animal Health) at a dose of $0.25 \mathrm{mg} / \mathrm{kg}$ was given slowly intravenously to reverse the effects of the medetomidine. The turtle recovered uneventfully one hour after the end of surgery.

Postoperative therapy consisted of keeping the turtle out of the tank enclosure for two days and alternating daily between saline $(0 \cdot 9$ per cent sodium chloride) and fresh water soaks lasting between 15 minutes and one hour. The turtle was given ampicillin intramuscularly at a dose of $5 \mathrm{mg} / \mathrm{kg}$ once a day and amikacin intramuscularly at $2.5 \mathrm{mg} / \mathrm{kg}$ every 72 hours. Two drops of neomycin-polymyxin B-dexamethasone $0 \cdot 1$ per cent ophthalmic suspension were administered to each eye three times a day; the eyes were flushed with saline ophthalmic solution before the topical medications were applied. Butorphanol (Torbugesic; Fort Dodge Animal Health) at a dose of $0.2 \mathrm{mg} / \mathrm{kg}$ was given intramuscularly on the night of the surgery and the day after, to sedate the turtle in an attempt to prevent self-induced trauma to the surgical sites.

The turtle's eyes were examined one week and three weeks after surgery. At the first examination mild corneal oedema was observed at the incision sites. Both aphacic eyes had positive menace and pupillary light responses, no aqueous flare, and mild residual capsular opacification. Both corneal incisions were healing, and the pupils were not dyscoric. The applications of topical antibiotic-corticosteroid ophthalmic solution were decreased to twice a day. The turtle was returned to the water tank enclosure 11 days after surgery. On the evidence of the turtle's ability to navigate and find food within the enclosure its visual function had markedly improved. By the second ophthalmic examination the incisions had healed completely, the corneal oedema had resolved and the anterior chambers remained clear. However, the sutures at the incision site were showing only minimal signs of resorption. Two months after the surgery, small circular, white plaque-like lesions were visible at the sutures in both eyes; they were thought to be focal suture granulomas. One month later these lesions were slowly resorbing, with only two present in one eye, but mild corneal oedema and scarring remained (Fig 2). The turtle's vision appeared to be nearly normal; it was able to navigate within its enclosure, avoid objects, and identify and take items of food. The turtle was later tagged with a National Marine Fisheries Service flipper tag and a passive integrated transponder and released off the coast of Marathon, Florida. Approximately nine months later it was found dead in a fishing net along the coast of North Carolina. A postmortem examination was performed on site. The curved length and width of its carapace were both $76 \cdot 2$ 
$\mathrm{cm}$. It was not weighed, but it was in good body condition as evidence by the amount of fat observed. The tissues were too autolysed for histopathology.

\section{DISCUSSION}

The possible causes of cataracts in turtles include poor nutrition (Vanisi and others 1981, Remillard and others 1993, Ranz and others 2002, Wegener and others 2002), genetic factors (Yakely 1978, Collins and others 1992, Bjerkas and Haaland 1995, Lehmann and others 2000), cataractogenic drugs and toxins (Costa and others 1996, Davidson and Nelms 1999), inflammation from trauma or infection (Davidson and Nelms 1999), and ultraviolet radiation (Paterson and Delamere 1992). Poor nutrition or uveitis associated with systemic disease seem the most likely aetiologies in this case, because of the age of the turtle, the lack of signs of external ocular trauma and the fact that the cataracts were bilateral. However, the precise aetiology is unclear because of the lack of history.

Phacoemulsification is the most common surgical technique for the removal of cataracts in human beings and animals (Miller and others 1987, Davidson and others 1991, Wilkie 1995, Williams and others 1996, Gilger 1997, Glover and Constantinescu 1997, Keil and Davidson 2001). The success of cataract surgery decreases with the presence of lensinduced uveitis and with the stage of the cataract, hypermature cataracts having the lowest success rate (Lannek and Miller 2001, Zahn and Kostlin 2002). The success rate with phacoemulsification is 90 per cent or more, and it has a greater long-term success rate, and is less affected by lensinduced uveitis and the stage of the cataract than other surgical techniques (Costa and others 1996, Zahn and Kostlin 2001, 2002).

Extraction of the lens results in an eye that is hyperopic, or far-sighted (Gum and others 1999). Streak retinoscopy to measure the refractive error postoperatively in the turtle would have been ideal, but general anaesthesia would have been required for this procedure and retinoscopy would be very difficult in a sea turtle. The placement of a synthetic intraocular lens can help to correct the hyperopia, but because of the marked difference in the size, shape, and refractile properties of the reptile eye, there was no appropriate lens implant available.

It is not known whether the turtle was predisposed to injury as a result of vision loss or other complications. However, its migration from the Florida Keys to North Carolina, approximately $1600 \mathrm{~km}$ in distance, its good body condition when found dead, and its growth during the nine months it was living wild suggest that the technique may be a suitable treatment for sea turtles with cataracts.

\section{ACKNOWLEDGEMENTS}

The authors thank the Virginia Marine Science Museum staff for their intensive care of the turtle and technical assistance with this case, the Virginia Beach General Hospital for the serum biochemical analyses, Dr Michael Stoskopf for his helpful comments on the manuscript, and Bill Tiernan from The Virginian Pilot for the photograph in Fig 1.

\section{References}

ALLEN, W. H. (1992) Increased dangers to Caribbean marine ecosystems. BioScience 42, 330-335

BALAZS, G. H. (1985) Impact of ocean debris on marine turtles: entanglemen and ingestion. Proceedings of the Workshop on the Fate and Impact of Marine Debris. Honolulu, USA, November 26 to 29, 1984. National Oceanic and Atmospheric Administration Technical Memorandum NMFS-SWFC 54, 387429

BALAZS, G. H., POOLEY, S. G. \& MURAKAWA, S. K. K. (1995) Guideline for handling marine turtles hooked or entangled in the Hawaii longline fishery. Results of an expert workshop. Honolulu, USA, March 15 to 27, 1995. National Oceanic and Atmospheric Administration Technical Memorandum NMFS-SWFC 222, 41

BJERKAS, E. \& HAALAND, M. B. (1995) Pulverulent nuclear cataract in the Norwegian buhund. Journal of Small Animal Practice 36, 471-474

BROOKS, D. E., GINN, P. E., MILLER, T. R., BRANSON, L. \& JACOBSON, E. R. (1994) Ocular fibropapillomas of green turtles (Chelonia mydas). Veterinary Pathology 31, 335-339

CHITTICK, E. J., STAMPER, A., BEASLEY, J. F., LEWBART, G. A. \& HORNE, W. A. (2002) Medetomidine, ketamine, and sevoflurane for anesthesia of injured loggerhead sea turtles: 13 cases (1996-2000). Journal of the American Veterinary Medical Association 221, 1019-1025

COLLINS, B. K., COLLIER, L. L., JOHNSON, G. S., SHIBUYA, H., MOORE, C. P. \& DA SILVA CURIEL, J. M. A. (1992) Familial cataracts and concurrent ocular anomalies in chow chows. Journal of the American Veterinary Medical Association 200, 1485-1491

COSTA, P. D., MERIDETH, R. E. \& SIGLER, R. L. (1996) Cataracts in dogs after long-term ketoconazole therapy. Veterinary and Comparative Ophthalmology 6, 176-180

DAVIDSON, M. G., NASISSE, M. P., JAMIESON, V. E., ENGLISH, R. V. \& OLIVERO, D. K. (1991) Phacoemulsification and intraocular lens implantation: a study of surgical results in 182 dogs. Progress in Veterinary Comparative Ophthalmology 1, 233-238

DAVIDSON, M. G. \& NELMS, S. R. (1999) Diseases of the lens and cataract formation. In Veterinary Ophthalmology. 3rd edn. Ed K. Gelatt. Philadelphia, Lippincott Williams \& Wilkins. pp 797-826

ECKERT, K. L. \& HONEBRINK, T. D. (1992) WIDECAST sea turtle recovery action plan for St Kitts and Nevis. Caribbean Environment Programme Technical Report 17. Kingston, United Nations Environment Programme GEORGE, R. H. (1995) Health problems and diseases of sea turtles. In Biology and Conservation of Sea Turtles. 2nd edn. Ed K. A. Bjorndal. Washington, Smithsonian Institute Press. pp 363-385

GILGER, B. C. (1997) Phacoemulsification technology and fundamentals. Veterinary Clinics of North America: Small Animal Practice 27, 1131-1141

GLOVER, T. D. \& CONSTANTINESCU, G. M. (1997) Surgery for cataracts. Veterinary Clinics of North America: Small Animal Practice 27, 1143-1173

GORDON, A. N., KELLY, W. R. \& CRIBB, T. H. (1998) Lesions caused by cardiovascular flukes (Digenea: Spirorchidae) in stranded green turtles (Chelonia mydas). Veterinary Pathology 35, 21-30

GORDON, A. N., KELLY, W. R. \& LESTER, R. J. G. (1993) Epizootic mortality of free-living green turtles, Chelonia mydas, due to coccidiosis. Journal of Wildlife Disease 29, 490-494

GROOMBRIDGE, B. (1990) Marine turtles in the Mediterranean: distribution, population status, conservation. Report to the Council of Europe Environment and Management Division. Nature and Environment Series No 48. pp 1-98

GUM, G. G., GELATT, K. N. \& OFRI, R. (1999) Physiology of the eye. In Veterinary Ophthalmology. 3rd edn. Ed K. N. Gelatt. Philadelphia, Lippincott Williams \& Wilkins. pp 170-173

KEIL, S. M. \& DAVIDSON, H. J. (2001) Canine cataracts: a review of diagnostic and treatment procedures. Veterinary Medicine 96, 14-38

LACKOVICH, J. K., BROWN, D. R., HOMER, B. L., GARBER, R. L., MADER, D. R., MORETTI, R. H., PATTERSON, A. D., HERBST, L. H., OROS, J., JACOBSEN, E. R., CURRY, S. S. \& KLEIN, P. A. (1999) Association of herpesvirus with fibropapillomatosis of the green turtle Chelonia mydas and the loggerhead turtle Caretta caretta in Florida. Diseases of Aquatic Organisms 37, 89-97

LANNEK, E. B. \& MILLER, P. E. (2001) Development of glaucoma after phacoemulsification for removal of cataracts in dogs: 22 cases (1987-1997). Journal of the American Veterinary Medical Association 218, 70-76

LEHMANN, K., STUR, I. \& WALDE, I. (2000) Hereditary eye diseases in the Austrian English Cocker Spaniel - a population genetic study. Wiener Tierärztliche Monatsschrift 87, 286-292

LIMPUS, C. \& REIMER, D. (1994) The loggerhead turtle, Caretta caretta, in Queensland: a population in decline. Proceedings of the Australian Marine Turtle Conservation Workshop. Gold Coast, Australia, November 14 to 17, 1990. pp 39-59

LUTCAVAGE, M. E., LUTZ, P. L., BOSSART, G. D. \& HUDSON, D. M. (1995) Physiologic and clinicopathologic effects of crude oil on loggerhead sea turtles. Archives of Environmental Contamination and Toxicology 28, 417-422 MEYLAN, A., SCHROEDER, B. \& MOSIER, A. (1995) Sea turtle nesting activity in the state of Florida, 1979-1992. Florida Marine Research Publication 52. St Petersburg, Department of Environmental Protection, Florida Marine Research Institute. pp 1-51 
MILLER, T. R., WHITLEY, D. R., MEEK, L. A., GARCIA, A. G., WILSON, M. C. \& RAWLS, B. H. (1987) Phacoemulsification and aspiration for cataract extraction in dogs: 56 cases (1980-1984). Journal of the American Veterinary Medical Association 190, 1577-1580

MILLICHAMP, N. J., JACOBSEN, E. R. \& WOLF, E. D. (1983) Diseases of the eye and ocular adnexae in reptiles. Journal of the American Veterinary Medical Association 183, 1205-1212

NATIONAL RESEARCH COUNCIL (1990) Decline of the sea turtles: causes and prevention. Washington, National Academy Press

NISHEMURA, W. \& NAKAHIGASHI, S. (1990) Incidental capture of sea turtles by Japanese research and training vessels: results of a questionnaire. Marine Turtle Newsletter 51, 1-4

PATERSON, C. A. \& DELAMERE, N. A. (1992) The lens. In Adler's Physiology of the Eye. 9th edn. Ed W. M. Hart. St Louis, Mosby Year Book. pp 348-390 PRITCHARD, P. C. (1997) Evolution, phylogeny, and current status. In The Biology of Sea Turtles. Eds P. L. Lutz, J. A. Musick. Boca Raton, CRC Press. pp 1-28

RANZ, D., GUTBROD, F., EULE, C. \& KIENZLE, E. (2002) Nutritional lens opacities in two litters of Newfoundland dogs. Journal of Nutrition 132, 1688S-1689S

REICHART, H. A. \& FRETEY, J. (1993) WIDECAST sea turtle recovery action plan for Suriname. Caribbean Environment Programme Technical Report 24. Kingston, United Nations Environment Programme. pp 1-65

REMILLARD, R. L., PICKETT, J. P., THATCHER, C. D. \& DAVENPORT, D. J. (1993) Comparison of kittens fed queen's milk with those fed milk replacers. American Journal of Veterinary Research 521, 901-907

VANISI, S., EDELHAUSER, H., WOLF, D., COTLIER, E. \& REESER, F. (1981) Nutritional cataracts in timber wolves. Journal of the American Veterinary Medical Association 179, 1175-1180

VIRGINIA INSTITUTE OF MARINE SCIENCE (2005) VIMS Sea Turtle Stranding Program. www.fisheries.vims.edu/turtletracking/stsp.html. Accessed February 23, 2005

WEGENER, A., GOLUBNITSCHAJA, O., BREIPOHL, W., SCHILD, H. H. \& VRENSEN, G. F. J. M. (2002) Effects of dietary deficiency of selective amino acids on the function of the cornea and lens in rats. Amino Acids 1-3,337-342 WETHERALL, J. A., BALAZS, G. H., TOKUNAGA, R. A. \& YONG, M. Y. Y.
(1993) Bycatch of marine turtles in North Pacific high-seas driftnet fisherie and impacts on stocks. North Pacific Commission Bulletin 53, 519-538

WHITAKER, B. R. \& KRUM, H. (1999) Medical management of sea turtles in aquaria. In Zoo and Wildlife Medicine. 4th edn. Ed M. Fowler. Philadelphia, W. B. Saunders. pp 217-231

WILKIE, D. A. (1995) Must you do phacoemulsification to be a successful cataract surgeon? Veterinary and Comparative Ophthalmology 5, 124-126

WILLIAMS, D. L., BOYDELL, I. P. \& LONG, R. D. (1996) Current concepts in the management of canine cataract: a survey of techniques used by surgeon in Britain, Europe, and USA and a review of recent literature. Veterinary Record 138, 347-353

WILLIAMS, E. H., Jr, BUNKLEY-WILLIAMS, L., PETERS, E. C., PINTO RODRIGUEZ, B., MATOS-MORALES, R., MIGNUCCI-GIANNONI, A. A HALL, K., RUEDA-ALMONACID, J. V., SYSBESMA, J., DECALVENTI, I. B. \& BOULON, R. H. (1994) An epizootic of cutaneous fibropapillomas in green turtles Chelonia mydas of the Caribbean: part of a panzootic. Journal of Aquatic Animal Health 6, 70-78

WITHERINGTON, B. E. \& MARTIN, R. E. (1996) Understanding, assessing and resolving light-pollution problems on sea turtle nesting beaches. Florida Marine Research Publication TR-2. St Petersburg, Department of Environmental Protection, Florida Marine Research Institute. pp 1-73

WITZELL, W. N. \& TEAS, W. G. (1994) The impacts of anthropogenic debris on marine turtles in the western north Atlantic ocean. National Oceanic and Atmospheric Administration Technical Memorandum NMFS-SEFSC 355, 1-21

WOLKE, R. E., BROOKS, D. R. \& GEORGE, A. (1982) Spirorchidiasis in log gerhead sea turtles (Caretta caretta): pathology. Journal of Wildlife Disease 18, 175-185

YAKELY, W. L. (1978) A study of heritability of cataracts in the American Cocker Spaniel. Journal of the American Veterinary Medical Association 172, 814-817

ZAHN, K. \& KOSTLIN, R. (2001) Lens surgery in dogs - retro and prospective evaluation of 230 eye surgeries. Part 1: indications, surgical methods and intraoperative complications. Tierärztliche Praxis. Ausgabe K, Kleintiere Heimtiere 29, 164-172

ZAHN, K. \& KOSTLIN, R. (2002) Lens surgery in dogs. Part 2: postoperative complications and results of 140 cataract extractions. Tierärztliche Praxis. Ausgabe K, Kleintiere Heimtiere 30, 28-35 